\title{
DEVELOPMENT OF WOOD-USING INDUSTRIES
}

$\mathrm{U}$ NDOUB'TEDLY among the most significant happenings of the past twelve months for the future of forestry and timber in Great Britain has been the publication of two reports on economic studies carried out by a Canadian firm of consulting engineers, Messrs. Sandwell and Co., Ltd., of Vancouver. These reports are entitled "Small Pulp Mill Survey" and "Board Mill Survey", respectively, the former having been conducted under the auspices of the Organization for European Economic Co-operation, the United Kingdom being one of seven member countries studied, while the latter was undertaken for selected regions in Great Britain at the request of the Forestry Commission*.

There are two reasons why such surveys were called for. First, the wood-pulp industry in Europe is very largely concentrated in Scandinavia, the remaining countries importing either pulp or materials made from it, such as paper or fibreboard ; naturally, it was desirable to see if something could be done in the home country to reduce dependence on imports and to develop new industries. Secondly, as a consequence of the extensive afforestation programmes of the past three or four decades, a very large volume of wood is becoming available, mostly from the small trees removed in the thinnings that must be carried out to make it possible for the trees retained in the forest to grow to saw-timber size within a reasonable time. This amount is not only already large, but also is increasing annually-and will continue to do so for a long time yet-while one of its main markets, namely, pit-wood for the coal mines, is approaching saturation ; Scotland's needs are already met entirely from Scotland's own forests, and the demand is showing signs of falling off.

Basic to these studies are the facts that Britain imports three-quarters of a million tons of paper and boards out of her annual consumption of 4 million tons (1956 figures), and production in Britain of the balance is dependent on the import of 2 million tons of pulp. Expressed otherwise, three-quarters of the wood that is consumed by the British paper industry is imported.

It has always been recognized that for a pulp mill to be profitable there are several essential requirements which are not easy to fulfil. Only three of these requirements need be mentioned here: (1) a large and regular supply of suitable wood; (2) the cost of that supply delivered at the mill must be low compared with the price that is paid in the existing markets for such material for other uses such as pit-wood, light poles and box-wood; (3) a good water supply with effective means of disposal of effluents.

The consultants have tried to answer two main questions : (1) Given a delivered cost for wood, what is the minimum capacity of a pulp mill to be economically feasible under any of the processes available? (2) If the output is to be as low as 30 tons

* (1) Forestry Commission. Small Pulp Mull Survey, United Kingdom-Economic Study, By Sandwell and Co., Ltd. Pp. iv +43 . 48. net. (2) Board Mill Survey, United Kingdom-Economic Study. By Sandwell and Co., Ltd. Pp. vi +70 . (London : H.M. Stationery
Office, 1959.) 5s. net. per diem, at what price must wood be available ? It is not possible here to discuss the details; but their findings are that a separate plant set up solely to produce ground-wood (that is, mechanical) pulp is out of the question; that for a chemical (bleached sulphate) pulp plant receiving its raw material at a price that would be viewed as so low as to be doubtfully attainable by United Kingdom growersthough it is the average top price prevailing in North America-namely, $£ 8$ 10s. a ton, the plant would have to be able to turn out at least 80 tons of pulp a day. If its capacity were as low as 30 tons a day, the price that it could afford to pay for the wood would be altogether impossibly low.

The overall conclusion is that if Britain is to develop in this field, her pulp mill must be integrated with other wood-based industries, notably with papermaking, like the recently opened hardwood pulp mill at Chepstow. Integration with saw-milling and connected industries such as veneering, plywood and furniture would also be helpful by providing an appreciable proportion of the raw material from waste available on the spot at a very low cost. If this can be done, a relatively small mill of 30-40 tons capacity should be able to pay a price for the rest of its wood which, though still lower than is currently being obtained, can be viewed as not impossibly so.

It is estimated that by 1965 two centres in Scotland (Inverness and Fort William) would probably be producing enough wood surplus within 100 miles radius by road to support a small-scale pulp mill if it can pay something like the current price for its wood, but probably only ten years later if its price is appreciably lower. At least two other centres are expected to have a similar surplus by 1975 . It is known that a proposition to site such a mill in Scotland is under serious consideration by a leading group of wood industrialists. Incidentally, it has to be noted that our paper is mostly made of blended materials, including large amounts of straw-of which much more would be available if needed-and imported pulp of a type that would be selected in relation to the properties of that obtained from the local materials.

The second survey deals with the possible establishment of further hardboard, chipboard and insulating board mills, using the same raw material from the thinnings of our plantations. Although the amount of hardboard we import to-day corresponds to a production of $\mathbf{5 0 0}$ tons per diem, it is concluded that its manufacture would not be economically attractive unless the raw material could be cheapened to an extent that, as for the pulp mill, would only be attainable by integration with other wood industries, and this is not currently a practicable proposition with sawmilling because this industry is at present dispersed among a very large number of relatively small units. It is emphasized that chipboard and insulating board mills also require to be large to be reasonably profitable, with a daily output of at least 50 tons. They would be able to pay a rather higher 
price for their wood than that quoted for the pulp mill, a price that is still lower than the grower is at present getting, but within the range that he might he able to accept without putting himself out of business, provided every possible economy was made. Capital requirements would be about $£ 1-2$ million. In contrast with the prospects of further pulp mills, the most favourable area for board mills is considered to be southern England.

In the light of these surveys, it seems likely that Britain will have new wood-using mills of either or both types being built in the coming decade. There are not a few criticisms of the premises underlying these Sandwell reports with regard to costs, prices and trends, and suggestions that the size for profitability, at least for board mills, could be rather smaller and the capital cost less. However, it seems agreed that there must be a considerable reduction of the costs of growing and delivering the large amounts of wood required, and that there is certainly room for reduction by improved efficiency all along the line ; there will be every incentive for cheaper production as other markets are bound to fall during what, without such mills, will be a period of large over-production. In all cases there will be marketing problems, especially in view of the free competition of imports under the Outer Seven trade agreements, but cautious optimism appears justifiable, and expansion in the directions indicated is to be expected in the near future.

H. Champion

\section{BIOCHEMISTRY AT THE IMPERIAL COLLEGE OF SCIENCE AND TECHNOLOGY, LONDON}

T HE Imperial College of Science and Technology, London, has accepted a benefaction of $£ 350,000$ from the Isaac Wolfson Foundation to build and equip new laboratories for biochemistry and chemical microbiology and to support teaching and research in these subjects. Dr. E. B. Chain has been appointed to the chair of biochemistry and will take up the appointment in $\mathbf{1 9 6 1 .}$

This munificent benefaction will enable the College to erect a new building, to be known as the Wolfson Laboratory, adjacent to the Royal College of Science building in Imperial Institute Road. The Biochemistry Department will also occupy some laboratories in the Royal College of Science building shortly to be vacated by the Physics Department for its large new building in Prince Consort Road. Biochemistry at the College, which has been under the direction of a reader since the last occupant of the chair, Prof. A. C. Chibnall, succeeded Gowland Hopkins at Cambridge during the War, will thus burgeon out. The Department's new equipment will include fermentation units of comparatively large size and workshops for advanced mechanical and electronie equipment. It will provide accommodation for training and research in the neglected borderland between biochemistry and chemical engineering, and for research on an adequate scale on the biochemical production of chemicals of interest. Such a department, set in the Imperial College, with its very large school of engineering and flourishing schools of physics, organic chemistry and plant physiology, should find conditions highly propitious for major advances in biochemical knowledge.

Dr. Chain has since 1948 been at the Istituto Superiore di Sanità in Rome, where he has built up one of the best equipped, largest and most active centres of biochemical research in Europe. He has had there many of the facilities for which he had earlier, and unsuccessfully, pressed in Great Britainin particular, equipment of pilot-plant scale for fundamental studies of substances of microbial origin and biochemical interest.

Dr. Chain, a graduate of the University of Berlin, was forced to leave Germany by Nazi persecution in 1933 , and he became a British subject in 1939 . He first worked under Gowland Hopkins at Cambridge, on snake venoms and phospholipids. In 1935 came an invitation from Prof. (now Sir Howard) Florey to join the scientific staff of the Sir William Dunn School of Pathology at Oxford, with the object of organizing a biochemistry section there. As University lecturer in chemical pathology he remained at Oxford until the end of 1948. His work there included a study of the biochemical mode of action of some snake venoms, on the mode of action of lysozyme, on the mode of action of the spreading factor, on tumour metabolism and on a rapid method for the determination of phosphate. In 1938, with Florey, a systematic study of anti-bacterial substances produced by micro-organisms was started. This led to the discovery of the curative properties of penicillin and heralded the era of antibioties. In this work he played a leading part in the chemical studies on the isolation and structure of penicillin. For his part in the discovery of penicillin he was awarded the Nobel Prize for Medicine and Physiology in 1945, jointly with Sir Alexander Fleming and Florey. Dr. Chain was elected to fellowship of the Royal Society in 1949.

At the Istituto Superiore di Sanitì, with the support of Prof. D. Marotta, director of the Institute, and the Italian Government, Dr. Chain has carried out research in many directions. His collaborators have included chemical, mechanical and electronics engineers, biochemists, organic chemists, microbiologists and geneticists. A wide range of subjects has been studied, mainly in two fields of biochemistry, chemical microbiology and intermediate carbohydrate metabolism in animals, touching on the methodological, biochemical and biological as well as the chemical engineering aspects of the subjects.

Among the biochemical subjects studied in the field of chemical microbiology have been factors involved in the biosynthesis of penicillin. The continuation of this work led to the discovery, by a team of research workers in the Beecham Laboratories in England, to which Dr. Chain has acted as adviser and consultant, that the main part of the penicillin molecule (6-aminopenicillanic acid) could be made by biosynthesis, and that this could be modified afterwards by chemical means. A great range of new antibiotics can be made in this way. They include a penicillin which is acid-stable and can be taken by 